\title{
Simulasi Perhitungan Unjuk Kerja / Performansi Boiler Pembangkit Listrik Tenaga Uap Berbahan Bakar Batu Bara
}

\author{
Abrar Ridwan, Legisnal Hakim, Budi Istana, Lobertus Gunawan Hasugian \\ Program Studi Teknik Mesin, Fakultas Teknik \\ Universitas Muhammadiyah Riau \\ e-mail: lobertusgunawan@gmail.com
}

\begin{abstract}
Abstrak
Perencanaan operasional yang tepat perlu dilakukan untuk meningkatkan efektifitas kerja PLTU Tanjung Balai Karimun karena berpengaruh langsung pada biaya operasional yang dikeluarkan oleh perusahaan. Performance setiap peralatan utama di PLTU khususnya Boiler perlu menjadi perhatian karena dari nilai efesiensi ini dapat dilihat langsung apakah sebuah pembangkit dapat dikatakan layak atau tidak untuk beroperasi. Semakin tinggi nilai efesiensi dari sebuah boiler maka unjuk kerjanya di lapangan juga bagus. Tujuan penelitian ini adalah Menghitung performance boiler dengan metode tidak langsung sesuai standar ASME PTC-4-1 Power Test Code Steam Generating Units sehingga dapat mengetahui neraca bahan dan energi yang lengkap untuk setiap aliran, yang dapat memudahkan dalam mengidentifikasi opsi-opsi untuk meningkatkan efisiensi boiler dan untuk memudahkan perhitungan efesiensi boiler dibuat software perhitungan yang dibangun berbasis macromedia flash. Dengan memasukkan data yang diambil langsung dari hasil pengujian performance di PLTU Tanjung Balai Karimun dihasilkan efisiensi boiler sebesar $82,7 \%$, dan Hasil perhitungan menggunakan aplikasi simulasi perhitungan ditemukan losses pada gas buang sebesar 5,14 \%, loosses pada hidrogen in fuel sebesar 5,34 \%, losses akibat moisture in fuel sebesar 5,47 \%, losses pada moisture in air sebesar $0,21 \%$, losses akibat pembakaran tidak sempurna sebesar $0,07 \%$, losses akibat radiasi dan konveksi sebesar 1,05\% dan losses akibat batu bara tidak terbakar pada fly ash sebesar 0,00008\% dan losses akibat batu bara tidak terbakar pada bottom ash sebesar 0,00021\% .
\end{abstract}

Kata kunci: performan,boiler, perhitungan, efisiensi

Kata kunci : Performan,boiler, perhitungan, efisiensi

\section{Pendahuluan}

Pembangunan PLTU Tanjung Balai Karimun 2x7 MW merupakan salah satu upaya yang dilakukan untuk mengatasi krisis penyediaan tenaga listrik di Indonesia khususnya Wilayah Riau dan Kepulauan Riau, dimana kebutuhan energi listrik semakin meningkat sejalan dengan pertumbuhan ekonomi, selain dengan pembangunan pembangkit listrik yang harus dapat mengimbangi kebutuhan masyarakat, juga dipandang perlu untuk memanfaatkan listrik secara efisien, baik dari segi penggunaan maupun proses pembangkitan energi listrik itu sendiri.

PLTU Tanjung Balai Karimun merupakan pembangkit baru sehingga kemungkinan turunnya efisiensi boiler dimasa akan datang pasti terjadi. Turunnya efisiensi boiler disebabkan antara lain: pembakaran yang tidak sempurna, kotornya permukaan penukar panas, buruknya operasi dan pemeliharaan PLTU. Dengan turunnya efisiensi boiler akan memberi dampak terhadap penurunan efisiensi keseluruhan unit pembangkit yang tidak mampu lagi menghasilkan daya sebesar pada saat komisioning yaitu $2 \times 7 \mathrm{MW}$, untuk itu efisiensi boiler harus terus dipantau dan di dijaga agar tidak turun.

Perhitungan efisiensi boiler dengan menggunakan rumus perpindahan panas termodinamika juga mempunyai beberapa kendala yaitu sangat tergantung pada tabel properti air, dan tidak dapat memberikan petunjuk penyebab dari efisiensi sistem yang lebih rendah dan tidak menghitung kehilangan yang berpengaruh pada berbagai tingkat efisiensi. sehingga penulis mencoba melakukan perhitungan dengan metode tidak langsung sesuai standar ASME PTC-4-1 Power Test Code Steam Generating Units sehingga dapat mengetahui neraca bahan dan energi yang lengkap untuk setiap aliran, yang dapat memudahkan dalam mengidentifikasi opsi-opsi untuk meningkatkan efisiensi boiler. Sementara itu ketepatan dan kecepatan perhitungan sangat diperlukan maka dibutuhkan pemrograman perhitungan dalam bentuk aplikasi.

Penurunan efisiensi boiler atau rugi kalor pada boiler sangat sulit di prediksi karena begitu 
kompleksnya parameter dan perhitungan yang digunakan. Dengan itu diperlukan aplikasi untuk pengkajian, perhitungan dan analisis efisiensi boiler yang dapat digunakan oleh operator maupun engineer di lapangan, sehingga dari analisa yang didapat nantinya diharapkan dapat dilakukan tindak lanjut perbaikan yang berdampak pada peningkatan efisiensi boiler, dan secara otomatis meningkatkan efisiensi PLTU Tanjung Balai Karimun secara keseluruhan.

\section{Methodologi}

Teknik pengumpulan data yang digunakan dalam penelitian ini adalah sebagai berikut:

\section{2..1. Studi Pustaka}

Mengumpulkan bahan-bahan yang berhubungan dengan permasalahan yang akan di bahas yang tersdapat pada buku maupun data yang ada di internet dan sumber lainnya.

\section{2. .Studi Lapangan}

Studi lapangan dimulai dari pencatatan, pengolahan, hingga penyimpanan data. pada bagian ini penulis mengambil data secara langsung dari data performance test PLTU Tanjung Balai Karimun tahun 2014.

\subsection{Peralatan yang Digunakan}

Setelah data diperoleh langkah selanjutnya merancang software yang nantinya digunakan untuk simulasi perhitungan. Dimulai dengan sketch untuk tampilan hingga coding. Untuk pembuatan software simulasi menggunakan macromedia flash professional 8.

Alat penelitian yang digunakan dalam penyusunan penelitian dibagi menjadi dua, yaitu hardware dan software. Alat yang digunakan sebagai berikut:

\section{Hardware}

a. Seperangkat komputer dengan spesifikasi : Processor : Intel(R) Pentium(TM) i7-4790 CPU @ 3.60GHz Memory (RAM) : 8.00 GB OS : Microsoft Windows XP Service Pack 2

b. Mouse dan Keyboard

\section{Software}

Macromedia Flash Professional 8 Merupakan software utama dalam pembuatan aplikasi ini. Software ini dapat menmpilkan gabungan antara grafik, suara, teks, animasi yang akan yang disimpan menjadi *.fla.

\section{Langkah-langkah Penyelesaian/Flow chart penelitian}

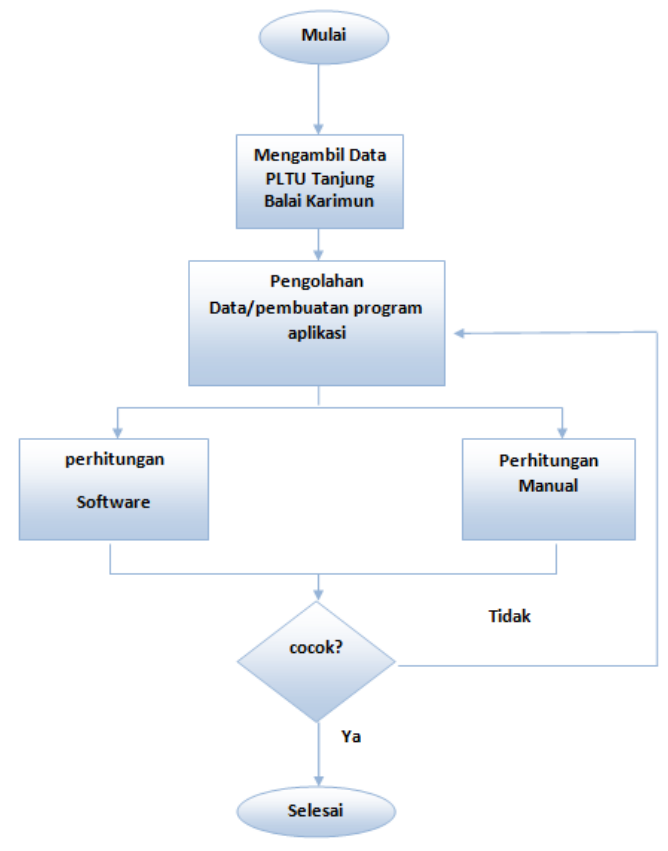

Gambar 1. Flowchart penelitian

\section{Hasil dan Pembahasan}

\subsection{Spesifikasi Boiler.}

PLTU Tanjung Balai Karimun menggunakan firing system stocker dengan kapasitas steam output 40 ton/jam dengan tekanan steam sebesar $52 \mathrm{~kg} / \mathrm{cm}^{2} \mathrm{~g}$ dan temperatur $490{ }^{0} \mathrm{C}$, feed water temperatur masuk ke boiler sebesar $164{ }^{0} \mathrm{C}$, sistem aliran udara menggunakan Balanced Draft dengan force draft fan sebagai pendorong udara masuk dan induced draft fan untuk menghisap udara gas buang dari furnance boiler.

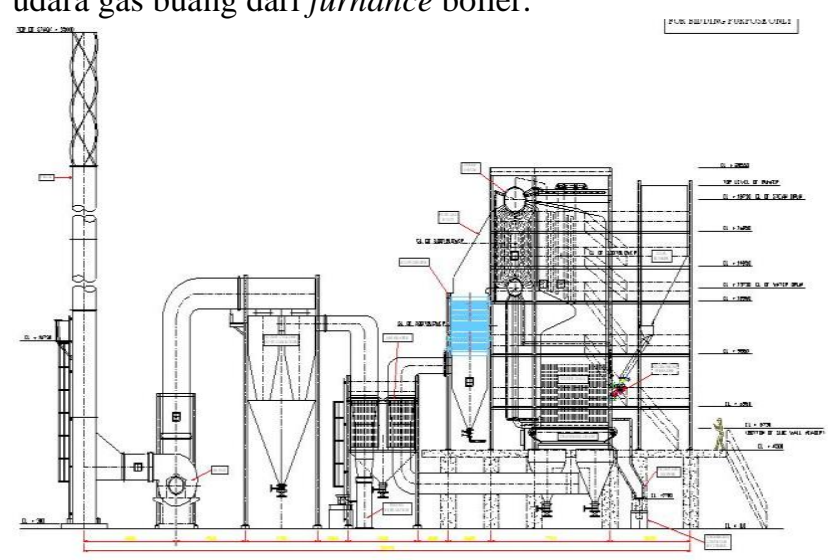

Gambar 2. Desain Boiler

(Sumber : manual book PLTU, 2012) 
Spesifikasi teknis boiler pada PLTU Tanjung Balai Karimun sebagai berikut:

Tabel 1. Spesifikasi Boiler

\begin{tabular}{|c|c|c|c|}
\hline \multirow{2}{*}{$\begin{array}{rr}\mathbf{A} S \\
\\
\end{array}$} & \multicolumn{3}{|l|}{$\begin{array}{l}\text { Steam } \\
\text { Generation } \\
\end{array}$} \\
\hline & Manufacturer & & DEN \\
\hline & Steam Generator & 40 & Ton/Hour \\
\hline & Feed Water temp. & 164 & ${ }^{0} \mathrm{C}$ \\
\hline & Outlet pressure & 52 & $\mathrm{Kg} / \mathrm{cm}^{2} \mathrm{~g}$ \\
\hline & $\begin{array}{l}\text { Superheater } \\
\text { outlet }\end{array}$ & 490 & ${ }^{0} \mathrm{C}$ \\
\hline & Precipicator & & Multicyclone \\
\hline & Firing system & & Stocker \\
\hline & Draft system & & Balanced draft \\
\hline & $\begin{array}{l}\text { Boiler heating } \\
\text { surface }\end{array}$ & & Approx $1730 \mathrm{~m}^{2}$ \\
\hline $\mathbf{B}$ & stoker & & \\
\hline 1 & Motor & & \\
\hline & Type & & Traveling grate stoker \\
\hline & Daya & 2.2 & $\mathrm{~kW}$ \\
\hline & Kecepatan & $1.2-1.3$ & Rpm \\
\hline & Tegangan & 380 & Volt \\
\hline & Frekuensi & 50 & $\mathrm{~Hz}$ \\
\hline & Phase & 3 & Phase \\
\hline 2 & Chain grate & & \\
\hline & Final reduction & $1: 63$ & $\begin{array}{l}\text { Ratio Worm/bevel } \\
\text { gear box }\end{array}$ \\
\hline & Safety devices & & Torque guard \\
\hline & Stoker speed & $\begin{array}{r}1.035- \\
10.35 \\
\end{array}$ & $\mathrm{~m} / \mathrm{hr}$ \\
\hline 3 & Steam drum & & \\
\hline & $\begin{array}{l}\text { Operation } \\
\text { pressure }\end{array}$ & 61.6 & Bar \\
\hline & $\begin{array}{l}\text { Operation } \\
\text { temperature }\end{array}$ & 279.0 & ${ }^{0} \mathrm{C}$ \\
\hline
\end{tabular}

\subsection{Data Sheet Test Boiler Performance.}

Berikut ini adalah data atau parameter yang diambil sewaktu pengetesan performance boiler dilakukan. Data ini nantinya dibutuhkan untuk melakukan perhitungan performansi dari boiler. adapun parameter yang diukur antara lain hasil analisisi ultimate batu bara, pengukuran ambient air, referensi temperatur, ash dan slag, dan kandungan gas yang diukur pada stack boiler.

Tabel 2. Data Sheet ultimate analisis batu bara

\begin{tabular}{lcl}
\hline Uraian & Nilai & \\
\hline \hline & & \\
carbon air dried basis & 42,05 & $\%$ \\
& 0,421 & $\mathrm{Kg} / \mathrm{kg}$ \\
Hidrogen air dried basis & 3,70 & $\%$ \\
& 0,037 & $\mathrm{Kg} / \mathrm{kg}$ \\
Oxigen air dried basis & 14,35 & $\%$ \\
& 0,1435 & $\mathrm{Kg} / \mathrm{kg}$ \\
Nitrogen air dried basis & 0,36 & $\%$ \\
& 0,0036 & $\mathrm{Kg} / \mathrm{kg}$ \\
Sulphur air dried basis & 0,22 & $\%$ \\
& 0.002 & $\mathrm{Kg} / \mathrm{kg}$ \\
Moisture air dried basis & 34,10 & $\%$ \\
& 0,341 & $\mathrm{Kg} / \mathrm{kg}$ \\
Ash air dried basis & 5,22 & $\%$ \\
& 0,0522 & $\mathrm{Kg} / \mathrm{kg}$ \\
Volatile matter air dried basis & 32,84 & $\%$ \\
& 0,3284 & $\mathrm{Kg} / \mathrm{kg}$ \\
Higher heat value as receive & 4.018 & $\mathrm{kcal} / \mathrm{kg}$ \\
(HHV) & $16.822,562$ & $\mathrm{KJ} / \mathrm{kg}$ \\
& $3.628,00$ & $\mathrm{kcal} / \mathrm{kg}$ \\
Low heat value as receive & & \\
(LHV) & $15.189,710$ & $\mathrm{KJ} / \mathrm{kg}$ \\
\hline
\end{tabular}

Tabel 3. Data Sheet ambient air

\begin{tabular}{|c|c|c|}
\hline Uraian & Nilai & \\
\hline \multirow{3}{*}{$\begin{array}{l}\text { Nilai pengukuran barometric pada } \\
\text { daerah boiler }\end{array}$} & 755,250 & $\mathrm{mmHg}$ \\
\hline & $1.006,917$ & Mmbar \\
\hline & 100,692 & $\mathrm{kPa}$ \\
\hline $\begin{array}{l}\text { Tw = ambient air temperature } \\
\text { (wet bulb) }\end{array}$ & 28,640 & ${ }^{0} \mathrm{C}$ \\
\hline $\begin{array}{l}\mathrm{Td}=\text { ambient air temperature (dry } \\
\text { bulb) }\end{array}$ & 29,170 & ${ }^{0} \mathrm{C}$ \\
\hline $\begin{array}{l}\text { Relative humidity dengan } \\
\text { Hygrometer }\end{array}$ & 85,880 & $\%$ \\
\hline $\begin{array}{l}\text { Slag remover temperature /bottom } \\
\text { ash/ ash cooler }\end{array}$ & 47,400 & ${ }^{0} \mathrm{C}$ \\
\hline $\mathrm{Pb}=$ saturated vapor pressure & $3.998,911$ & $\mathrm{~Pa}$ \\
\hline Wma = absolute humidity & 0.022 & \\
\hline
\end{tabular}

Tabel 4. Data Sheet referensi temperatur

\begin{tabular}{lrl}
\hline \multicolumn{1}{c}{ Uraian } & \multicolumn{2}{c}{ Nilai } \\
\hline Rreference air temperature dry bulb & 33 & ${ }^{0} \mathrm{C}$ \\
\hline $\begin{array}{l}\text { Entalpy of saturated vapor at } \\
\text { reference temperature }\end{array}$ & $2.560,95$ & $\mathrm{~kJ} / \mathrm{kg}$ \\
\hline $\begin{array}{l}\text { entalpy of satureated } \mathrm{H} 2 \mathrm{O} \text { at } \\
\text { reference temperature }\end{array}$ & 138,274 & $\mathrm{~kJ} / \mathrm{kg}$ \\
\hline
\end{tabular}


Tabel 5. Data Sheet ash \& slag

\begin{tabular}{lrl}
\hline Uraian & Nilai & \\
& & \\
\hline \hline & & \\
Gas temperatur leaving air heater & 162,2 & ${ }^{0} \mathrm{C}$ \\
& 86 & \\
$\mathrm{t}_{\mathrm{g} 15}$ correction & 164,0 & ${ }^{0} \mathrm{C}$ \\
& 52 & \\
Unburned carbon in fly ash & 1,18 & $\%$ \\
& 0,012 & $\mathrm{Kg} / \mathrm{kg}$ \\
Unburned carbon in bottom ash & 2,20 & $\%$ \\
& 0,022 & $\mathrm{~kg} / \mathrm{kg}$ \\
Average unburned carbon in ash & 0,013 & $\%$ \\
Dry refuse per kg of ash fired coal & 0,052 & $\mathrm{~kg} / \mathrm{kg}$ \\
Carbon burned per kg as fired coal & 0,420 & $\mathrm{~kg} / \mathrm{kg}$ \\
Spesific heat of flue dust at average & 0,20 & $\mathrm{Btu} / \mathrm{lb}$ \\
flue dust temperature & & ${ }^{0} \mathrm{~F}$ \\
& 0,837 & $\mathrm{~kJ} / \mathrm{kg}$ \\
& & $\mathrm{C}$ \\
Average bottom ash temperature & 47,40 & ${ }^{0} \mathrm{C}$ \\
& 0 & \\
Spesific heat of bottom ash at & 0,25 & $\mathrm{Btu} / \mathrm{lb}$ \\
average bottom ash temperature & & ${ }^{0} \mathrm{~F}$ \\
& 1,047 & $\mathrm{~kJ} / \mathrm{kg}{ }^{0}$ \\
& & $\mathrm{C}$ \\
\hline
\end{tabular}

Tabel 6. Data Sheet gas

\begin{tabular}{lrl}
\hline Uraian & Nilai & \\
\hline \hline & & \\
Oxigen measure & 2,459 & $\%$ \\
Carbon dioxide & 16,135 & $\%$ \\
Carbon monoxide & 0,019 & $\%$ \\
\hline
\end{tabular}

\subsection{Perhitungan Performansi Boiler Secara} Manual.

Setelah pengambilan data dilakukan kemudian dapat dihitung performansi boiler dengan menggunakan formula sesuai dengan standar perhitungan metode tidak langsung. adapun tahapan perhitungannya sebagai berikut:

\section{Tahap 1. Menghitung Kebutuhan Udara Teoritis}

$$
\begin{aligned}
& \text { Kebutuhan Udara Teoritis }= \\
& =\quad\left[(11.6 \times \mathrm{C})+\left\{34.8 \times\left(\mathrm{H}_{2}-\mathrm{O}_{2} / 8\right)\right\}+\right. \\
& \quad(4.35 \times \mathrm{X} \mathrm{S})] / 100 \mathrm{~kg} / \mathrm{kg} \text { batu bara } \\
& =\quad[(11.6 \times 42.05)+\{34.8 \times(3.7-14.35 / 8)\} \\
& \quad+(4.35 \times 0.22)] / 100 \mathrm{~kg} / \mathrm{kg} \text { batu bara } \\
& =\quad 5,47 \mathrm{~kg} / \mathrm{kg} \text { batu bara }
\end{aligned}
$$

Tahap 2. Menghitung persen kelebihan udara yang dipasok (EA).

$\% \mathrm{CO} 2$ secara teoritis : :

$$
\begin{aligned}
& =\frac{\mathrm{mol} \mathrm{C}}{\text { mol N2 }+ \text { mol C }} \\
& =\frac{\text { Wt N2 pada udara teoritis }}{\text { Mol Wt N2 }}+\frac{\text { Wt N2 pada fuel }}{\text { Mol Wt N2 }}
\end{aligned}
$$

$$
=\frac{5,54 \times 77 / 100}{28}+\frac{0,0036}{28}=0,019
$$

Mol C

$$
\begin{aligned}
& =\frac{0,4205}{12} \\
& =0,04 \\
& =\frac{0,04}{0,04+0,019} \times 100 \% \\
& =18,68 \%
\end{aligned}
$$

Tahap 3. Excess Air yang di pasok.

$\%$ Excess Air Supplied (EA) :

$$
\begin{aligned}
& =\frac{7900 \times\{(\text { CO2\% } t-(\text { CO2\% } a\}}{(\text { CO2\% }) a \times\{100-(\text { CO2\% }) t} \\
& =\frac{7900 \times\{(18,68 \%) t-(16,135 \%) a\}}{(16,135 \%) a \times\{100-(18,68 \%) t} \\
& =15,35 \%
\end{aligned}
$$

Tahap 4 . Menghitung Massa Udara Aktual Yang dipasok (AAS)

$$
\begin{aligned}
\text { Massa udara aktual } & =\left\{1+\frac{E A}{100}\right\} \times \text { Udara teoritis } \\
& =\left\{1+\frac{15,35}{100}\right\} \times 5,54 \\
& =\mathbf{6}, 39 \mathrm{~kg} / \mathbf{k g} \text { bahan bakar }
\end{aligned}
$$

Tahap 5. Menghitung massa gas buang aktual (m)

$$
\begin{array}{ll}
\text { Massa gas } & =\text { Massa CO2 } \\
\text { buang aktual } & + \text { Massa Kandungan N2 Pada Bahan Bakar } \\
& + \text { Massa N2 Dalam Udara Pembakaran } \\
& + \text { Massa O2 Dalam Gas Buang } \\
& =\frac{0,4205 \times 44}{12}+0,0036+\frac{6,39 \times 77}{100}+\frac{(6,39-5,54) \times 23}{100} \\
& =6,66 \mathrm{~kg} / \mathrm{kg} \text { bahan bakar }
\end{array}
$$

Tahap 6. Memperkirakan seluruh kehilangan panas.

i. Presentase kehilangan panas yang diakibatkan oleh gas buang yang kering.

$$
\begin{aligned}
\mathrm{L} 1 & =\frac{m \times C p \times(T f-T a) \times 100}{G C V \text { Bahan Bakar }} \\
& =\frac{6,66 \times 0.23 \times(164,052-29,17) \times 100}{4.018} \\
& =5,14 \%
\end{aligned}
$$




\section{1) Pembuatan Obyek dan Background}

Pembuatan obyek (baik obyek diam maupun bergerak) dan background pada aplikasi ini digambar secara manual dengan memanfaatkan tools pada Macromedia Flash. Untuk menggambar garis maupun bidang menggunakan fasilitas line tool sedangkan untuk pewarnaannya menggunakan fasilitas paint bucket tool. Efek animasi obyek pada aplikasi ini menggunakan teknik animasi mengubah alpha, tint serta motion tween. Proses pembuatan background pada aplikasi ini sama dengan proses pembuatan obyek, tetapi lebih banyak pada penggunaan permainan kombinasi warna dengan menggunakan fasilitas tool color mixer dengan tipe linear maupun radial. Obyek maupun gambar background yang telah digambar diconvert menjadi simbol dengan tipe graphic maupun movie clip. Hal ini dimaksudkan agar gambar obyek maupun background tersimpan di panel library sehingga dapat digunakan kembali yaitu dengan cara men-drag gambar ke area kerja. Tampilan pembuatan objek dan backround dapat dilihat pada Gambar 3.

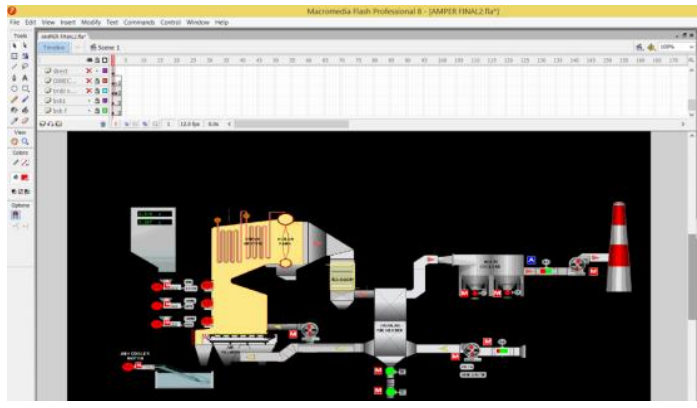

Gambar 3. Tampilan Pembuatan Obyek dan Backround

\section{2) Pembuatan Tampilan awal}

Pembuatan tampilan awal masing-masing obyek dipisahkan kedalam beberapa layer yang bertujuan untuk mempermudah dalam pembuatan animasi dan penyusunan terhadap obyek yang telah digambar. Dalam membuat animasi, langkah yang perlu dilakukan terlebih dahulu adalah meng-convert simbol obyek dari bentuk graphic menjadi movie clip, kemudian obyek tersebut diubah posisi dan bentuknya dari frame satu ke frame lainnya untuk memperoleh hasil animasi bergerak. Untuk menjalankan dan memperhalus gerakannya, digunakan teknik animasi motion tween. Tampilan pembuatan intro dapat dilihat pada Gambar 4.

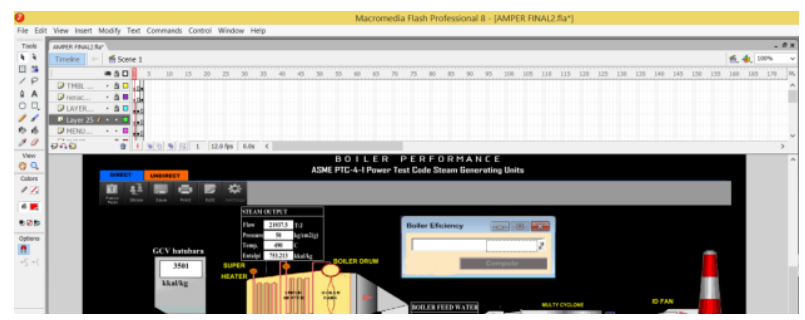

Gambar 4. Pembuatan tampilan awal

\section{3) Pembuatan Tombol Navigasi}

Tombol navigasi pada aplikasi berfungsi untuk menuju ke halaman tertentu. Tombol navigasi dibuat dengan cara meng-convert graphic yang telah digambar dengan menggunakan fasilitas line tool, text tool dan beberapa obyek atau gambar menjadi simbol dengan tipe button. Masing- masing tombol pada aplikasi ini disisipkan suara yang telah disiapkan. Tombol keluar dan tombol menu terdapat pada semua halaman kecuali halaman loading, halaman intro dan halaman keluar. Tampilan pembuatan tombol navigasi dapat dilihat pada Gambar 5 dan 6.

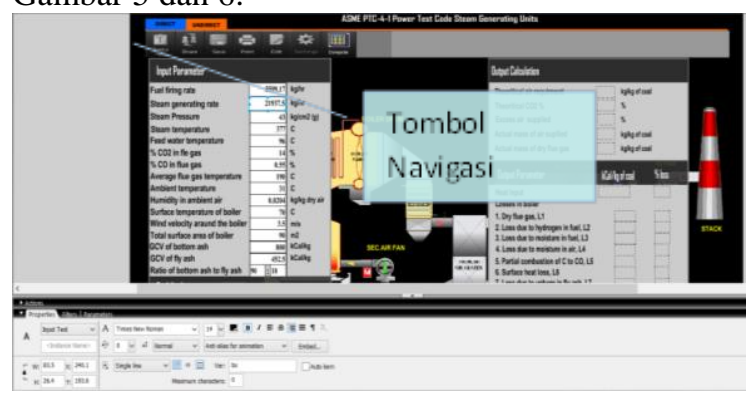

Gambar 5. Tampilan Pembuatan Tombol Navigasi

\section{4) Pemrograman dengan Actionscript}

Actionscript digunakan untuk menjalankan aksi pada frame, movie clip maupun pada suatu tombol. Beberapa actionscript yang digunakan dalam aplikasi multimedia ini adalah sebagai berikut :

\section{a. Actionscript pada awal frame}

fscommand ("fullscreen", "true");

Penjelasan : Maksud dari script di atas adalah ketika aplikasi ini dijalankan maka aplikasi ini akan tampil secara penuh (fullscreen).
b. Actionscript pada tombol untuk menu navigasi
on (release)
\{nextFrame(); \} 
Penjelasan : Maksud dari script di atas adalah ketika tombol di klik maka secara otomatis akan memindahkan frame ke frame selanjutnya. dimana navigasi aplikasi diseimpan dalam frame yang berbeda.

\section{c. Action script pada tombol perhitungan \\ on (release) \{}

$$
a z
$$

$((11.6 *$ Number $($ sx $))+(34.8 *($ Number $(t x)$ $-(\operatorname{Number}(v x) / 8)))+(4.35 * 0)) / 100$

$b z=(($ Number $($ sx $) / 1200) /(($ Number $($ sx $) / 1$ 200) $+(($ Number $(a z) * 77 / 2800)+($ Numbe $r(u x) / 2800)))) * 100$

$c z \quad=\quad((7900 *(N u m b e r(b z)-$ Number $(f x))) /($ Number $(f x) *(100$ -

Number(bz))))

$d z$

$(1+($ Number $(c z) / 100)) * N u m b e r(a z)$

$e z$

$($ Number $(s x) * 44 / 1200)+(N u m b e r(u x) / 1$

$00)+($ Number $(d z) * 77 / 100)+(($ Number $(d$ z) -4.91$) * 23 / 100$ )

Penjelasan : Maksud dari script di atas adalah ketika tombol di klik maka secara otomatis aplikasi akan menghitung semua looses yang terjadi pada boiler sesuai dengan input parameter yang diisikan.

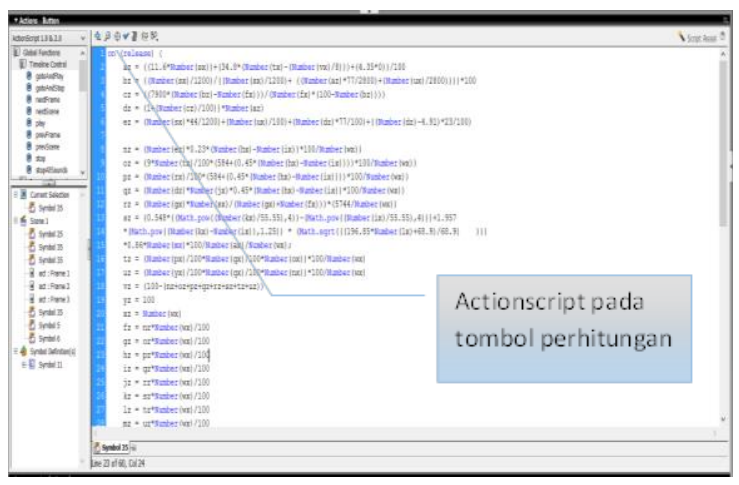

Gambar 6. Tampilan Pembuatan actionscript

\subsection{Pembuatan Pengujian Aplikasi}

Halaman awal merupakan halaman yang muncul pertama. Pada halaman ini berisi metode perhitungan langsung (Direct) performance boiler. Tampilan halaman Metode perhitungan langsung dilihat pada Gambar 6.

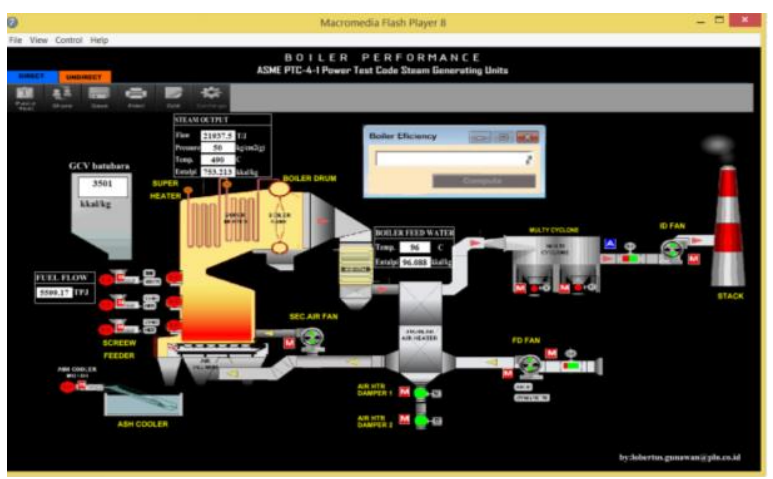

Gambar 7. Tampilan Halaman awal

Halaman kedua merupakan halaman yang berisi metode perhitungan tidak langsung (Indirect Method) performance boiler. Tampilan halaman menu dapat dilihat pada Gambar 7.



Gambar 8. Tampilan Halaman kedua

Halaman ini menjelaskan tentang ringkasa neraca besaran heat losses yang terjadi pada boiler. Pada halaman ini juga terdapat tombol navigasi yaitu tombol keluar untuk kembali ke menu utama Tampilan halaman Neraca Energi dapat dilihat pada Gambar 4.8.

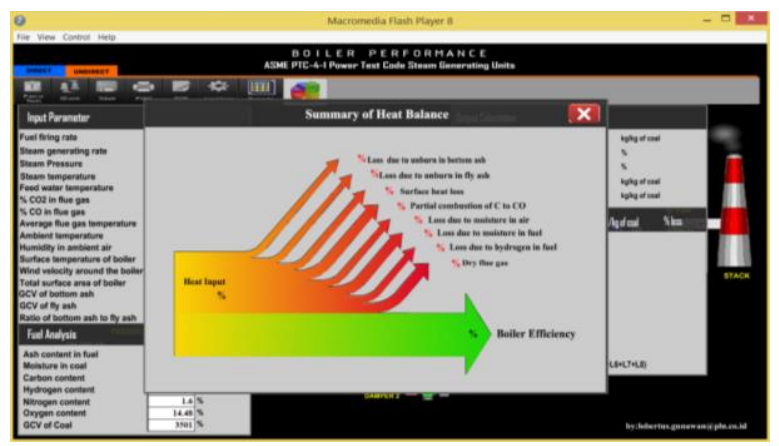

Gambar 9. Tampilan Halaman Neraca Energi 


\subsection{Perhitungan Menggunakan Aplikasi Simulasi yang dibuat}

Perhitungan performance boiler dengan menggunakan aplikasi ini sangat mudah dilakukan, hal pertama yang dilakukan adalah memilih metode perhitungan yaitu indirect method, kemudian pada input parameter masukkan nilai masing-masing parameter sesuai dengan data sheet. Input parameter terdiri dari data parameter boiler yaitu fuel firing rate, steam generating rate, steam pressure, $\% \mathrm{CO}_{2}$ in flue gas, \% CO in flue gas, average flue gas temperature, ambient air temperature, humidity in ambient air, surface temperature of boiler, wind velocity around boiler, total surface of boiler, GCV of bottom ash, GCV of fly ash, rasio of bottm ash to fly ash. pada fuel analisis diisikan parameter berupa kandungan yang terdapat pada batu bara seperti ash conten, moisture conten, carbon conten, hidrogen conten, nitrogen conten, oksigen conten dan gross caloric value $(G C V)$ dari batu bara yang digunakan.

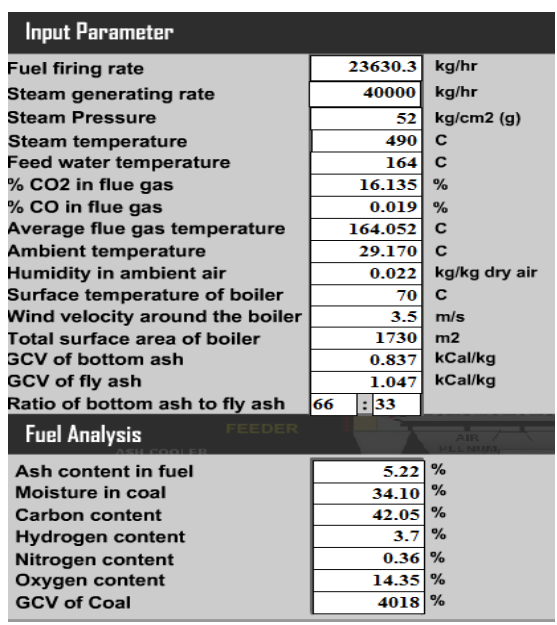

Gambar 10. Tampilan Input Parameter

Setelah nilai parameter input dimasukkan, kemudian tekan tombol calculate pada aplikasi menu, maka hasil perhitungan efisiensi boiler akan meampilakan output calculation secara detail mulai dari teoritical air requirmen, jumlah udara aktual yang dipasok, jumlah excess air yang disuplai, kemudian pada output parameter akan ditampilakn heat loss/ kerugian panas berupa dry flue gas, kerugian akibat kandungan hydrogen pada batu bara, kerugian akibat radiasi dan konveksi, dll.

Hasil perhitungan dapat kita lihat dalam bentuk heat balance diagram dimana efisiensi boiler sebesar $82,70 \%$, dengan loses pada gas buang sebesar $5,14 \%$, looses pada hidrogen in fuel sebesar 5,34 \%, loses akibat moisture in fuel sebesar $5,47 \%$, loses pada moisture in air sebesar $0,21 \%$, loses akibat pembakaran tidak sempurna sebesar $0,07 \%$, loses akibat radiasi dan konveksi sebesar $1,05 \%$ dan loses akibat batu bara tidak terbakar pada fly ash sebesar $0,00008 \%$ dan loses akibat batu bara tidak terbakar pada bottom ash sebesar $0,00021 \%$.

\begin{tabular}{|c|c|c|c|}
\hline \multicolumn{4}{|l|}{ Dutput Calculation } \\
\hline Theoritical air requirement & \multicolumn{3}{|c|}{$5.54 \mathrm{~kg} / \mathrm{kg}$ of coal } \\
\hline Theoritical $\mathrm{CO} 2 \%$ & 18.68 & $\%$ & \\
\hline Excess air supplied & 15.34 & \multicolumn{2}{|l|}{$\%$} \\
\hline Actual mass of air supllied & 6.39 & \multicolumn{2}{|l|}{ kglkg of coal } \\
\hline Actual mass of dry flue gas & \multicolumn{3}{|c|}{$6.66 \mathrm{~kg} / \mathrm{kg}$ of coal } \\
\hline Dutput Parameter & \multicolumn{2}{|c|}{ Whal/kg of coal } & \%lass \\
\hline $\begin{array}{l}\text { Heat Input } \\
\text { Losses in boiler }\end{array}$ & \multicolumn{2}{|r|}{4018} & 100 \\
\hline 1. Dry flue gas, L1 & \multicolumn{2}{|r|}{206.68} & 5.14 \\
\hline 2. Loss due to hydrogen in fuel, $\mathrm{L} 2$ & \multicolumn{2}{|r|}{214.68} & 5.34 \\
\hline 3. Loss due to moisture in fuel, $\mathrm{L} 3$ & \multicolumn{2}{|r|}{219.84} & 5.47 \\
\hline 4. Loss due to moisture in air, L4 & \multicolumn{2}{|r|}{8.53} & 0.21 \\
\hline 5. Partial combustion of $\mathrm{C}$ to $\mathrm{CO}, \mathrm{L} 5$ & \multicolumn{2}{|r|}{2.84} & 0.07 \\
\hline 6. Surface heat loss, L6 & \multirow{2}{*}{\multicolumn{2}{|c|}{$\begin{array}{r}42.26 \\
0.01\end{array}$}} & 1.05 \\
\hline 7. Loss due to unburn in fly ash, L7 & & & 0 \\
\hline 8. Loss due tu unburn in bottom ash, L8 & \multicolumn{2}{|r|}{$\begin{array}{l}0.01 \\
0.02\end{array}$} & 0 \\
\hline \multicolumn{3}{|c|}{ Boiler Efficiency $=100-(L 1+L 2+L 3+L 4+L 5+L 6+L 7+L 8)$} & 82.7 \\
\hline
\end{tabular}

Gambar 11. Tampilan Hasil Perhitungan

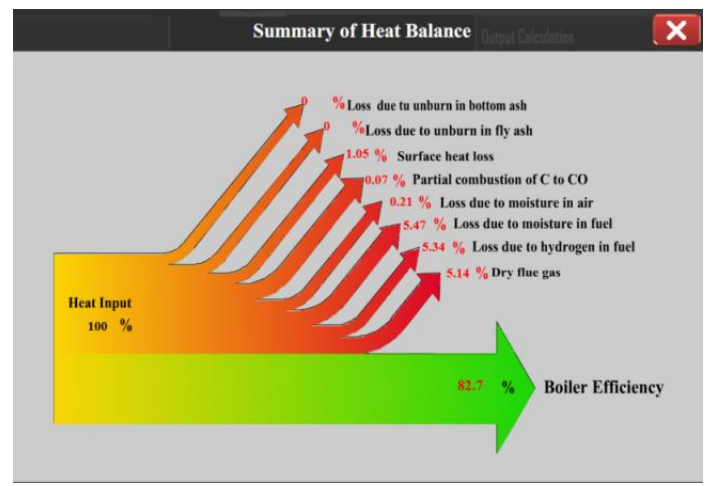

Gambar 12. Heat Balance Diagram

Hasil perhitungan menggunakan simulasi dihasilkan efisiensi sebesar $82,70 \%$, dan apabila kita bandingkan dengan hasil perhitungan manual sebesar $82,70 \%$ maka dapat kita pastikan bahwa perhitungan dengan menggunakan aplikasi telah sesuai dengan perhitungan secara manual.

\subsection{Peluang Efisiensi Energi}

Peluang efisiensi energi berhubungan dengan pembakaran, perpindahan panas, kehilangan yang dapat dihindarkan, konsumsi energi untuk alat pembantu, kualitas air dan blow down. berikut ini adalah beberapa peluang efisiensi 
yang dapat diambil guna meningkatkan efisiensi boiler.

\section{Pengurangan kandungan air pada batu bara}

Pengurangan kandungan air pada batu bara merupakan cara yang efektif dalam mengurangi pemakaian bahan bakar, dimana sesuai hasil perhitungan ditemukan bahwa kerugian kalor terbesar diakibatkan panas yang hilang karena penguapan uap air dalam bahan bakar yaitu sebesar 5,47 \%. kandungan air dalam bahan bakar dapa diakibatkan oleh curah hujan yang mengenai batu bara saat pengiriman baru bara maupun saat penyimpanan batu bara pada coal yard yang tidak dilengkapi dengan atap pelindung. sehingga untuk mengurangi kandungan air pada batu bara dilakukan dengan membuat atap penyimpanan/penumpukan batu bara.

\section{Pengendalian Suhu Cerobong}

Hasil perhitungan diketahui kerugian energi pada gas buang sebesar $5,14 \%$, dan untuk mengurangi kerugian kalor tersebut suhu cerobong harus dibuat serendah mungkin. walau demikian, suhu tersebut tidak boleh terlalu rendah sehingga uap air akan mengembun pada dinding cerobong. hal ini penting bagi bahan bakar yang mengandung sulfur dimana pada suhu rendah akan mengakibatkan korosi titik embun sulfur. suhu cerobong yang terlalu tinggi menandakan adanya potensi untuk pemanfaatan kembali limbah panas. hal ini juga menandakan telah terjadi pembentukan kerak pada peralatan perpindahan panas/pemanfaatan panas dan sebaikknya dilakukan shut down lebih awal untuk pembersihan air/ sisi cerobong.

\section{Pembakaran yang Tidak Sempurna.}

Pembakaran yang tidak sempurna dapat timbul dari kekurangan udara atau kelebihan bahan bakar atau buruknya pendistribusian bahan bakar. hal ini nyata terlihat dari warna atau asap dan kerugian kalor akibat konversi Carbon ke Carbon monoksida sebesar 0,07 \%, dan harus segera diperbaiki.dalam sistem pembakaran batubara, karbon ynag tidak terbakar dapat merupakan kehilangan yang besar. Ukuran bahan bakar yang tidak seragam dapat juga menjadi penyebab tidak sempurnanya pembakaran. pada chain grate stokers, bongkahan besar tidak akan terbakar sempurna, sementara potongan yang kecil dan halus akan menghambat aliran udara, sehingga menyebabkan buruknya distribusi udara.

\section{Pengendalian Udara Berlebih.}

Udara berlebih diperlukan pada seluruh praktek pembakaran untuk menjamin pembakaran yang sempurna, udara berlebih (excess air supplied) dari hasil perhitungan adalah sebesar 15,35 \% untuk memperoleh variasi pembakaran dan untuk menjamin kondisi cerobong yang memuaskan untuk beberapa bahan bakar. tingkat optimal udara berlebih untuk efisiensi boiler yang maksimum terjadi bila jumlah kehilangan yang diakibatkan pembakaran yang tidak sempurna dan kehilangan yang disebabkan oleh panas dalam gas buang diminimalkan.

\section{Meminimalisasi kehilangan panas radiasi dan konveksi}

Permukaan luar shell boiler lebih panas daripada sekitarnya. jadi, permukaan melepaskan panas ke lingkungan tergantung pada luas permukaan dan perbedaan suhu antara permukaan dan lingkungan sekitarnya.panas yang hilang dari shell boiler sesuai hasil perhitungan adalah sebesar 1,05\% merupakan kehilangan energi yang sudah tertentu, terlepas dari keluaran boiler. dengan rancangan boiler yang modern, kehilangan ini hanya sekitar 1,5 persen dari nilai kalor kotor pada kecepatan penuh, namun akan meningkat ke sekitar 6 persen jika boiler hanya beroperasi pada keluaran 25 persen.perbaikan atau pembesaran isolasi dapat mengurangi kehilangan panas pada dinding boiler dan pemipaan.

\section{Pengurangan Pembentukan Kerak dan Kehilangan Jelaga}

Boiler dengan menggunakan bahan bakar batubara mempunyai efek samping yaitu pembentukan jelaga pada dinding pipa boiler. jelaga yang terbentuk pada pipa-pipa bertindak sebgai isolator terhadap perpindahan panas, sehingga endapan tersebut harus dihilangkan secara teratur. suhu cerobong yang meningkat dapat menandakan pembentukan jelaga yang berlebihan. hasil yang sama juga akan terjadi karena pembentukan kerak pada sisi air. suhu gas keluar yang tinggi pada udara berlebih yang normal menandakan buruknya kinerja perpindahan panas. kondisi ini dapat diakibatkan dari pembentukan endapan secara bertahap pada sisi gas atau sisi air.

\section{Simpulan}

4.1. Simpulan 
1. Dengan menggunakan aplikasi Boiler Performance Simulator ini kita dapat melakukan evaluasi performance boiler secara cepat dan akurat.

2. Hasil perhitungan menggunakan simulasi dihasilkan efisiensi sebesar 82,7 \%, dan apabila kita bandingkan dengan hasil perhitungan manual sebesar 82,70 maka dapat kita pastikan bahwa perhitungan dengan menggunakan aplikasi telah sesuai dengan perhitungan secara manual.

3. Hasil perhitungan menggunakan aplikasi simulasi perhitungan ditemukan loses pada gas buang sebesar $5,14 \%$, looses pada hidrogen in fuel sebesar 5,34\%, loses akibat moisture in fuel sebesar $5,47 \%$, loses pada moisture in air sebesar $0,21 \%$, loses akibat pembakaran tidak sempurna sebesar 0,07 \%, loses akibat radiasi dan konveksi sebesar 1,05 $\%$ dan loses akibat batu bara tidak terbakar pada fly ash sebesar 0,00008\% dan loses akibat batu bara tidak terbakar pada bottom ash sebesar $0,00021 \%$.

\subsection{Saran}

Aplikasi simulasi perhitungan ini diharapakan dapat digunakan sebagai alat monitoring performansi boiler PLTU batu bara tipe stoker boiler. Kedepan aplikasi ini diharapkan dapat dikembangkan secara lebih lanjut agar dapat digunakan untuk menghitung performansi boiler dengan tipe dan bahan bakar yang berbeda.

\section{Daftar Pustaka}

[1] Asean Brown Bovery. (1991). Combustion Fossil Power, Combustion Engineering. Windsor Connecticut, Inc.

[2] Asean Brown Bovery.( 1994). Operation Manual Boiler Volume IX, New York.

[3] Djokosetyardjo.M.J.( 2003). Ketel Uap. Jakarta : Pradnya Paramita.

[4] Frank P. Incropera, David P. De Witt. (1996). Fundamental of Heat and Mass Transfer Edisi ke empat. New York : John wiley dan Sons.

[5] Harahap F. (1994). Termodinamika Teknik. Jakarta: Erlangga.

[6] J. Moran, Howard N. Shapiro. (2006). Fundamentals of engineering thermodynamics. England: John Wiley \& Sons, Inc.
[7] James R, Myers P.E. (2001). Combustion Improvements In Stoker Fired Boilers. Facilities Engineering Institute The Pennsylvania State University

[8] J.P. Holman. (1997). Perpindahan Kalor. Jakarta 13740: Erlangga Ciraca.

[9] Luhu. (2006). Audit Heat Balance pada Power Plant di PT. Indonesia Power. Surabaya: Jurusan Teknik Sistem Perkapalan, FTK-ITS.

[10] Michael F. Modest. Radiative Heat Transfer. Princeton Road s-1 Highstown NJ 68520: Mc Graw Hill, Inc.

[11] Muin S.A. (1988). Pesawat-Pesawat Konversi Energi I (Ketel Uap). Jakarta : Rajawali.

[12] Nursuhud D. (2006). Mesin Konversi Energi. Yogyakarta: Andi.

[13] Randall.D.T, Weeks. (1909). The Smokeless Combustion Of Coal in Boiler Plants .Washington: Goverment Printing Office.

[14] UNEP.(2016). United Nations Environment Programme-Greenhouse Gas Emission Reduction From Industri in Asia Pasific. India : National Productivity Council.

[15] Widhi H. Dhimas. (2009). Simulasi Kebutuhan Udara Pembakaran Boiler PLTU Indonesia Power Unit Bisnis Pembangkitan Perak. Surabaya: FTKITS. 